\title{
Effect of vernalization on seed production of onion
}

\author{
Esmat Jahan Ami' ${ }^{1}$, Md Torikul Islam ${ }^{2, ~ *, ~ A M ~ F a r o o q u e ~}{ }^{1}$ \\ ${ }^{1}$ Department of Horticulture, Bangladesh Agricultural University, Mymensingh-2202, Bangladesh \\ ${ }^{2}$ Departamento De Produccion Vexetal, Escuela Politecnica Superior. S/N 27007, Campus De Lugo. Universidade De Santiago De \\ Compostela, Spain
}

\section{Email address:}

mdtotrikul.islam@rai.usc.es(M. T. Islam)

\section{To cite this article:}

Esmat Jahan Ami, Md Torikul Islam, AM Farooque. Effect of Vernalization on Seed Production of Onion. Agriculture, Forestry and Fisheries. Vol. 2, No. 6, 2013, pp. 212-217. doi: 10.11648/j.aff.20130206.12

\begin{abstract}
An experiment was conducted at the Horticultural Farm, Bangladesh Agricultural University (BAU), Mymensingh during the period from October 2010 to April 2011. The present study was aimed at determining the effect of vernalization on the yield of onion seed. The experiment consisted three levels of Vernalization (viz., vernalization of mother bulbs at $5^{\circ} \mathrm{C} \pm 1$ and $10^{\circ} \mathrm{C} \pm 1$ and no vernalization). Bulbs of $20 \pm 1 \mathrm{~g}$ size of local cultivar Taherpuri were used as planting material and were vernalized at the duration of 14 days in freezing. Yield and quality of onion seeds significantly influenced by vernalization. Bulbs were vernalized in a refrigerator at a calibrated temperature of $5 \pm 1^{\circ} \mathrm{C}$ and $10 \pm 1^{\circ} \mathrm{C}$. Plant produced from the bulbs vernalized at $5 \pm 1{ }^{\circ} \mathrm{C}$ temperature prior to planting gave maximum leaves at 15,30 and 45 DAP $(19.91,26.47$ and 30.84 leaves per plant, respectively). Maximum seeds (189.05g) per umbel were produced by the plants that were vernalized in $5 \pm 1^{0} \mathrm{C}$. The highest seed yield per plot $(915.89 \mathrm{~g})$ was found from the cold treatment at $5 \pm 1^{\circ} \mathrm{C}$. Early plant emergence was noticed for longer vernalization treatment. Cold treatment of mother bulbs influenced the plant to produce maximum number of leaves.
\end{abstract}

Keywords: Onion, Vernalization, Bulb

\section{Introduction}

Onion (Allium cepa L.) is one of the most important winter spice crop grown during rabi season in Bangladesh. It ranks first in terms of area of cultivation and production amongst the bulb crops produced in the world (FAO, 2002). Among the spice crops grown in Bangladesh, it ranks second in respect of production and area (BBS, 2001). It is also used as preservative and medicine. In Bangladesh, the demand for onion is augmenting day by day; where the area under onion cultivation is not increasing rather it is decreasing. The average yield of onion in Bangladesh is only $3.45 \mathrm{t} / \mathrm{ha}$ (FAO, 2002). Onion is chiefly used as spice crop in Bangladesh. Its demand is increasing day by day with the increasing population of the country. It is cultivated all over the country but extensively cultivated in the Faridpur, Dhaka, Rajshahi, Comilla, Jessore, Dinajpur, Mymensingh, Rangpur, and Pabna. Bangladesh has produced 127 thousand metric ton onion bulbs from 34 thousand hectares of land during 20002001 growing season (BBS, 2001). The yield of onion in the country is very low (4018 kg/ha in 1998) as compared to the world average yield (17269 kg/ha) and it remained nearly same for the last five years (FAO, 1999). The unavailability of good quality onion seeds is partly responsible for low yield in Bangladesh (Bokshi et al., 1989).

Quality seed yield of onion depends on genotype, locality, season and method of seed production (Brewster, 1994). In Bangladesh 150 metric tons of onion seed were produced against an annual requirement of 300 metric tons (Rahim et al., 1993). Small amounts of seeds are produced in some districts like Faridpur, Natore and Rajshahi. There is a large gap prevailing in the country to meet up the requirements of onion seed.

Vernalization is a technique to initiate flowering in onion. Proper vernalization temperature of mother bulb stimulate early flowering and produces a heavier yield of seed (Jones and Mann, 1963). During the month of April and May, Nor'wester is a regular incidence in Bangladesh that affects the flower and flowering stalk to a great extent. Early flowering leading to early harvesting before the commencement of Nor'wester could save the onion seed crop. Hence, vernalization of mother bulbs might be a measure to ensure early flowering resulting in the production of early seed crop. 
The piece of research work was undertaken to find out the optimum vernalization temperature to achieve the best possible yield of the local variety of onion "Taherpuri" under the existing agroclimatic conditions of Bangladesh.

\section{Materials and Methods}

In this chapter the materials and methods that were used in carrying out the experiment have been described. Experimental sites, soil, experimental, material, methodology, design of experiment, raising of seed crop, data collection, statistical analysis of collected data have been described below.

\subsection{Experimental Site}

The present research work was conducted at the Horticultural Farm, Bangladesh Agricultural University, Mymensingh during the period from October 2010 to April 2011. The experimental area is located at $24^{0} 46^{\prime} \mathrm{N}$ latitude and $90^{\circ} 24^{\prime} \mathrm{E}$ longitude. The elevation of the area is approximately $19 \mathrm{~m}$ from average sea level.

\subsection{Soil}

The experimental area belongs to Old Brahmaputra Flood Plain (FAO, 1988) under the AEZ number-9. The field was a medium high land and above inundation level and texturally silty loam with a $\mathrm{pH}$ value 6.8 .

\subsection{Climate}

The climate of the experimental area was sub-tropical, characterized by heavy rainfall during the month of April to September and scanty rainfall during October to March (Anon.1999).

\subsection{Experimental Material}

Onion bulbs of the local cultivar, Taherpuri were collected from Durgapur of Rajshahi district, Bangladesh. The Average size of the bulb was $20 \pm 0.5 \mathrm{~g}$.

\subsection{Design and Layout of the Experiment}

The one-factor experiment was laid out in a randomized complete block design with three replications. In each block the land was divided into thirty-six plots in the experiment. The size of each unit plot was $1 \mathrm{~m} \times 1 \mathrm{~m}$.

\subsection{Experimental Treatments}

i. No vernalization at $\left(\mathrm{V}_{\mathrm{o}}\right)$ ii. Vernalization at $5 \pm 1^{0} \mathrm{C}\left(\mathrm{V}_{1}\right)$ iii. Vernalization at $10 \pm 1^{0} \mathrm{C}\left(\mathrm{V}_{2}\right)$

\subsection{Vernalization of Mother Bulbs}

Selected bulbs of the same size were put in white cotton cloth bags. Bulbs were then vernalized separately in a refrigerator calibrated at $10 \pm 1^{0} \mathrm{C}$ and $5 \pm 1^{0} \mathrm{C}$ and $25 \pm 3^{\circ} \mathrm{C}$.

\subsection{Cultural Operations}

\subsubsection{Land Preparation}

Land of the experiment field was opened on 06 October, 2011 with a disc plough drawn by a tractor. The soil was then allowed to dry up and subsequent ploughings were followed by a power tiller. Each ploughing was followed by laddering to break clods into small pieces. Weeds and stubbles were removed and the land was finally leveled by laddering. Thus it was prepared to a good tilth.

\subsubsection{Planting of Mother Bulbs}

Bulbs were taken out of the refrigerator 4 hours prior to planting and then kept under fan for 3 hours for surface drying. They were set at upright position (Novak, 1983) and at a depth of $2.5 \mathrm{~cm}$ (Bhardwaj et al., 1991).

\subsubsection{Gap Filling}

Rotten and unsprouted bulbs of the experimental plots were replaced by healthy ones of the same treatment from the border within 7 days of planting.

\subsubsection{Irrigation}

Afterwards irrigation was done by flood method. During irrigation care was taken to avoid water flow from one plot to another.

\subsubsection{Weeding}

Weeding was done for four times to keep the crop free from weeds and to break the soil crust. The major weeds were Cynodon dactylon L., Cyprus rotundus L., and Chenopodium album.

\subsubsection{Control of Diseases and Insects}

Rovral 50WP (2500 ppm ; HRDP,1995) was sprayed at 10 days interval to control purple blotch disease (caused by Alternaria porri). Dimcron 100WSC (2000 ppm; HRDP, 1995) was also sprayed once at 36 DAP to control onion thrips (Thrips tabaci).

\subsubsection{Staking}

Staking was provided by using dhaincha sticks to keep the scape erect and to protect them from lodging by strong wind and storm.

\subsubsection{Harvesting}

Mature seed umbels were harvested when 10-20\% capsule were splitted and exposed their black seed (Pandey et al., 1992). The seed crop was harvested from 12 March to 01 April, 2011.

\subsection{Data Collection}

To asses duration of vernalization on the yield and quality of onion seeds data on different growth, yield, and quality parameters were collected from starting of plant emergence to germination of the harvested seed. Data are collected from selected plants in each unit plot. To avoid border effect with the highest precision, 5 plants were selected randomly from each plot. 


\section{Results and Discussion}

\subsection{Effect of Vernalization on Plant Emergence (\%)}

Early plant emergence was observed in the bulbs which were vernalized before planting as compared to non vernalized ones. It was also found that the longer was the vernalization temperature the earlier and the higher was the plant emergence. It took 5 days to attain about $90 \%$ emergence for $5 \pm 1^{\circ} \mathrm{C}$ and $70 \%$ emergence for $10 \pm 1^{\circ} \mathrm{C}$ cold treated bulbs while it was about $45 \%$ plant emerged on the day 5 in case of non vernalized bulbs (Fig 1).

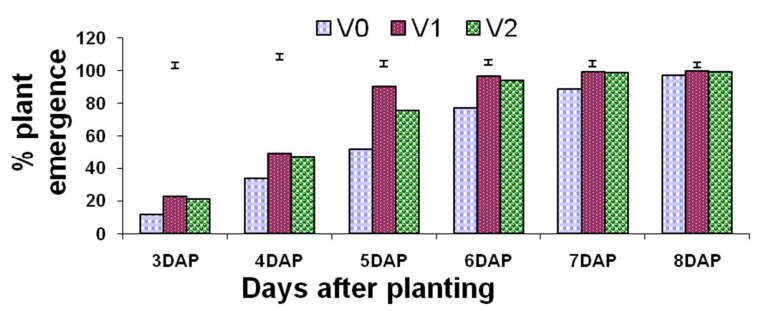

Figure 1. Effect of vernalization treatment on plant emergence in onion $\mathrm{cv}$. Taherpuri. $V_{o}=$ Control,$V_{1}=$ Vernalization at $5 \pm 1^{\circ} \mathrm{C}, V_{2}=$ Vernalization at $10 \pm 1^{\circ} \mathrm{C}$. Vertical bars indicate $L S D_{(0.05)}$.

\subsection{Effect of Vernalization on Number of Leaves / Plant}

Fig 2. Showed vernalization effect on leaves. Vernalization significantly influenced the number of green leaves at 15,30 and 45 DAP (Appendix III). Plant produced from the bulbs vernalized at $5 \pm 1^{\circ} \mathrm{C}$ temperature prior to planting gave maximum leaves at 15, 30 and $45 \operatorname{DAP}(19.91,26.47$ and 30.84 leaves per plant, respectively). The minimum number of green leaves were produced by the control treatment (bulbs stored at room temperature) at 15, 30 and 45 DAP (16.05, 19.66 and 26.03 per plant, respectively). Good foliage indicates higher growth, development and productivity of plant.

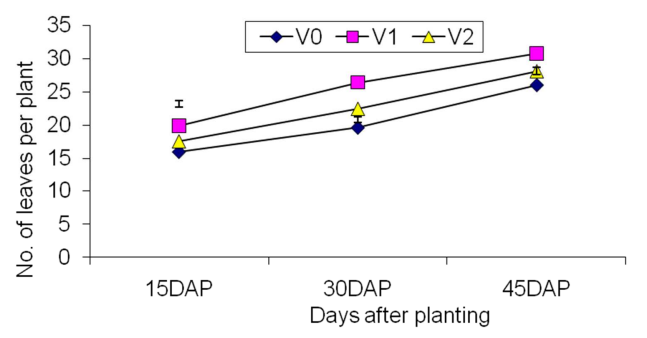

Figure 2. Effect of vernalization treatment on Number of leaves/ plant in onion. $V_{o}=$ Control,$V_{1}=$ Vernalization at $5 \pm 1^{\circ} C, V_{2}=$ Vernalization at $10 \pm 1^{\circ} \mathrm{C}$. Vertical bars indicate $L S D_{(0.05)}$.

\subsection{Effect of Vernalization on Plant Height}

Duration of vernalization significantly affected the plant height at 15, 30 and 45 DAP (Tab.1). At 15 DAP the tallest plant $(27.58 \mathrm{~cm})$ was obtained from the bulbs that were vernalized into $5 \pm 1^{\circ} \mathrm{C}\left(\mathrm{V}_{1}\right)$ temperature prior to planting. The shortest plant $(23.44 \mathrm{~cm})$ for the same was recorded from the bulbs having no vernalization treatment (control). Significantly tallest plant at 30 DAP and 45 DAP (38.05 and
$44.71 \mathrm{~cm}$ respectively) were produced by the bulbs those were vernalized into $5 \pm 1{ }^{\circ} \mathrm{C}$ temperature. Minimum plant height $(29.70 \mathrm{~cm}$ and $35.93 \mathrm{~cm}$ at 30 and $45 \mathrm{DAP})$ was recorded from the bulbs having no vernalization $\left(\mathrm{V}_{0}\right)$.

Table1. Effect of vernalization on plant height

\begin{tabular}{llll}
\hline $\begin{array}{l}\text { Vernalization } \\
\text { treatment }\end{array}$ & \multicolumn{2}{l}{ Plant height (cm) } \\
\hline $\mathrm{V}_{0}$ & $15 \mathrm{DAP}$ & 30DAP & 45DAP \\
$\mathrm{V}_{1}$ & 23.44 & 29.70 & 35.93 \\
$\mathrm{~V}_{2}$ & 27.58 & 38.05 & 44.71 \\
$\mathrm{LSD}$ at $5 \%$ & 26.59 & 35.75 & 42.06 \\
LSD at $1 \%$ & 0.485 & 0.560 & 0.544 \\
$\begin{array}{l}\text { Level of } \\
\text { significance }\end{array}$ & 0.680 & 0.785 & 0.763 \\
\hline
\end{tabular}

$\mathrm{V}_{\mathrm{o}}=$ Control, $\mathrm{V}_{1}=$ Vernalization at $5 \pm 1^{\circ} \mathrm{C}, \mathrm{V}_{2}=$ Vernalization at $10 \pm 1^{\circ} \mathrm{C}$,

$* *=$ significant at $1 \%$ level of probability

\subsection{Effect of Vernalization on Percent Flowering Plants}

Percent flowering plant was significantly increased with the increase in the cold treatment at the temperature $5 \pm 1^{\circ} \mathrm{C}$ $\left(\mathrm{V}_{1}\right) \quad(99.14 \%$ and $99.43 \%$ at 52 DAP and 57 DAP, respectively) (Tab. 2). Relevant results were published by Behairy and Habbasha (1979), Aguiar et al. (1983), Ramos and Ramos (1993) and Msika et al. (1997) who observed earlier and higher flowering for vernalized bulb planting. High temperature $\left(28-30^{\circ} \mathrm{C}\right)$ during storage inhibits inflorescence initiation and prevents floral initiation (Rabinowitch, 1990). On the other hand $8-12^{\circ} \mathrm{C}$ storage temperatures were optimum for the occurrence of such events (Brewster, 1994). The exposure to low temperatures either in natural winter or in artificial cold treatment that causes induction of flowering in several plant species, among them onion, is called vernalization (Pinthus, 1985; Flood \& Halloran, 1986).

Table 2. Effect vernalization on percent flowering plants

\begin{tabular}{|c|c|c|c|c|c|c|c|}
\hline \multirow{2}{*}{$\begin{array}{l}\text { Vernalizat } \\
\text { ion } \\
\text { treatment }\end{array}$} & \multicolumn{7}{|c|}{ Percent flowering plants } \\
\hline & $\begin{array}{l}27 \mathrm{D} \\
\text { AP }\end{array}$ & $\begin{array}{l}32 \mathrm{D} \\
\text { AP }\end{array}$ & $\begin{array}{l}37 \mathrm{D} \\
\text { AP }\end{array}$ & $\begin{array}{l}42 \mathrm{D} \\
\mathrm{AP}\end{array}$ & $\begin{array}{l}47 \mathrm{D} \\
\text { AP }\end{array}$ & $\begin{array}{l}52 \mathrm{D} \\
\mathrm{AP}\end{array}$ & $\begin{array}{l}57 \mathrm{D} \\
\mathrm{AP}\end{array}$ \\
\hline $\mathrm{V}_{0}$ & 4.26 & 42.06 & 53.34 & 66.00 & 85.19 & 91.94 & 96.43 \\
\hline $\mathrm{V}_{1}$ & 7.82 & 73.61 & 81.17 & 90.64 & 98.09 & 99.14 & 99.43 \\
\hline $\mathrm{V}_{2}$ & 6.46 & 68.82 & 78.69 & 88.26 & 96.27 & 97.80 & 99.15 \\
\hline LSD at $5 \%$ & 0.138 & 0.854 & 1.074 & 1.206 & 1.070 & 2.196 & 1.993 \\
\hline LSD at $1 \%$ & 0.193 & 1.198 & 1.505 & 1.691 & 1.501 & 3.079 & 2.794 \\
\hline $\begin{array}{l}\text { Level of } \\
\text { significanc } \\
e\end{array}$ & $* *$ & $* *$ & $* *$ & $* *$ & $* *$ & $* *$ & $* *$ \\
\hline
\end{tabular}

$\mathrm{V}_{\mathrm{o}}=$ Control, $\mathrm{V}_{1}=$ Vernalization at $5 \pm 1^{\circ} \mathrm{C}, \mathrm{V}_{2}=$ Vernalization at $10 \pm 1^{\circ} \mathrm{C}$ $* *=$ significant at $1 \%$ level of probability 


\subsection{Effect of Vernalization on Height of Flowering Stalk (cm)}

The longest scape $(99.98 \mathrm{~cm})$ was produced by the plants raised from the bulbs vernalized at $5 \pm 1^{\circ} \mathrm{C}$ and it was found to be statistically similar $(99.66 \mathrm{~cm})$ with the plant that received vernalization at $10 \pm 1^{\circ} \mathrm{C}$. The shortest $(97.40 \mathrm{~cm})$ flowering stalk was produced by the plant raised from the bulbs having no vernalization treatment (Fig. 3). It is known that most varieties of West Africa have a major handicap which is the emission of floral stalks I $\mathrm{n}$ the first year of cultivation. This phenomenon would greatly contribute to the reduction of yields in sensitive varieties (Rouamba, 1993; Sanders \& Cure, 1996). Several works have shown that the emission of floral stalks of the onion plant in the first year of cultivation, widely known as early flowering or bolting is due to climatic factors notably low temperatures.

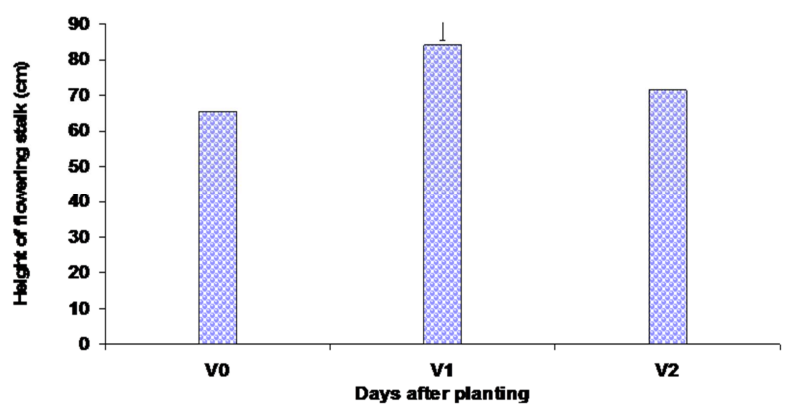

Figure 3. Effect of Vernalization on height of flowering stalk (cm). $V_{o}=$ Control,$\quad V_{1}=$ Vernalization at $5 \pm 1^{\circ} C, V_{2}=$ Vernalization at $10 \pm 1^{\circ} \mathrm{C}$. Vertical bars indicate $L S D_{(0.05)}$.

\subsection{Effect of Vernalization on the Number of Umbels/ Plant}

Vernalization treatment for $5 \pm 1^{\circ} \mathrm{C}$ temperature showed highest performance ( 99.98 per plant) but it was statistically similar to $10 \pm 1^{\circ} \mathrm{C}$ (99.66 per plant) vernalization treatment. The lowest number of umbels for the same parameter $(97.40$ per plant) was given by the bulbs without vernalization treatment (control) (Tab.3). Similar results were also reported by Aguiar (1984).

Table 3. Effect of vernalization on the number of umbel/ plant

\begin{tabular}{ll}
\hline Vernalization treatment & Number of umbels/plant \\
\hline $\mathrm{V}_{0}$ & 5.32 \\
$\mathrm{~V}_{1}$ & 8.30 \\
$\mathrm{~V}_{2}$ & 7.81 \\
$\mathrm{LSD}$ at $5 \%$ & 0.419 \\
LSD at $1 \%$ & 0.588 \\
Level of significance & $* *$ \\
\hline
\end{tabular}

$\mathrm{V}_{\mathrm{o}}=$ Control, $\mathrm{V}_{1}=$ Vernalization at $5 \pm 1^{\circ} \mathrm{C}, \mathrm{V}_{2}=$ Vernalization at $10 \pm 1^{\circ} \mathrm{C}$ $* *=$ significant at $1 \%$ level of probability

\subsection{Effect of Vernalization on the Number of Flower Buds Per Umbel}

It was apparent that maximum number of flower buds per umbel (250.20) was recorded in the plant raised from the $5 \pm 1^{\circ} \mathrm{C}$ cold treatment and it was statistically similar to $10 \pm 1{ }^{\circ} \mathrm{C}$ (203.82) cold treatment (Fig.4) The lowest number of flower buds per umbel (167.43) was recorded in the plant raised from no treatment $\left(\mathrm{V}_{0}\right)$.

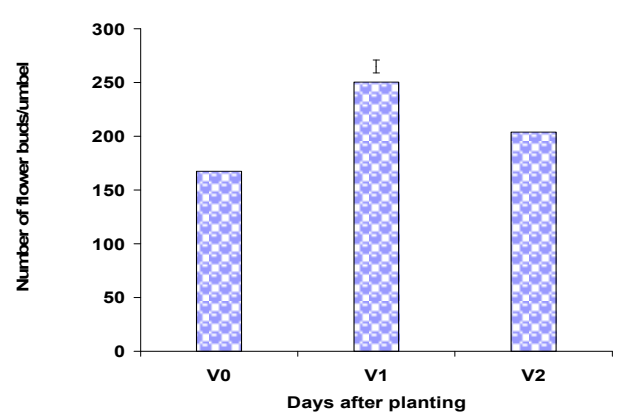

Figure 4. effect of vernalization on the number of flower buds per umbel. $V_{o}=$ Control, $V_{1}=$ Vernalization at $5 \pm 1^{\circ} \mathrm{C}, V_{2}=$ Vernalization at $10 \pm 1^{\circ} \mathrm{C}$. Vertical bars indicate $L S D_{(0.05)}$.

\subsection{Effect of Vernalization on Percent Hervested Umbels}

Cold treatment for $5 \pm 1^{\circ} \mathrm{C}$ showed early and rapid harvesting pattern. Thus it was obvious that cold treatment for $5 \pm 1{ }^{\circ} \mathrm{C}$ produce highest number 98.13 at 137 DAP. The lowest number produce (90.55) at 137 DAP (Fig.5). Cold treatment of bulb for $5 \pm 1^{\circ} \mathrm{C}$ and $10 \pm 1^{\circ} \mathrm{C}$ maintained statistical similarity within themselves in these regard. It was observed that $98.13 \%$ umbels were harvested at 137 DAP from $5 \pm 11^{\circ} \mathrm{C}$ treated plant while it was $90.55 \%$ for non vernalized plant.

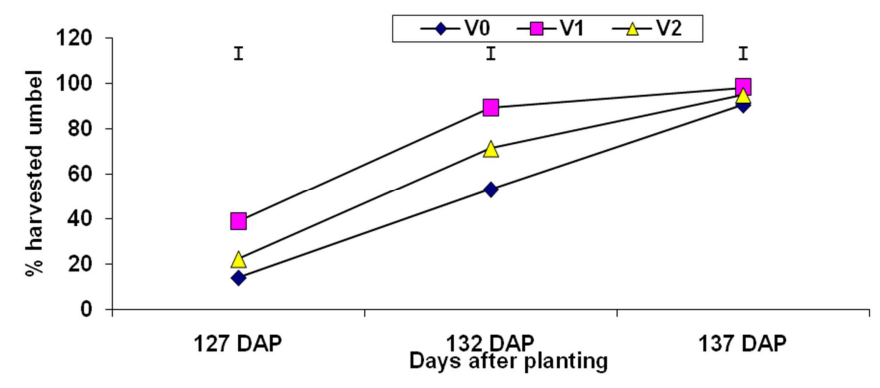

Figure 5. Effect of vernalization treatment on Percent harvested umbels in Onion. $V_{o}=$ Control, $V_{1}=$ Vernalization at $5 \pm 1^{\circ} C, V_{2}=$ Vernalization at $10 \pm 1^{\circ} \mathrm{C}$. Vertical bars indicate $\operatorname{LSD}(0.05)$.

\subsection{Effect of Vernalization on the Number of Seeded Fruits/Umbels}

The number of seeds per umbel was significantly varied due to different cold treatment. Duration of cold treatment at $5^{0} \mathrm{C}$ found to be the best (412.22 seeds/umbel) to produce seed in the umbel. The lowest number (218.43 seeds/umbel) was recorded from the bulbs planted without cold treatmentV0 (Tab.4). About the average temperatures prevailing during time of bulb production; we note that they 
were lower in the normal season $\left(17.33^{\circ} \mathrm{C}\right)$. As result, the bulbs from plants which do not bolt in such conditions produce seed (S22) with good resistance to bolt. Currah et al. (1993) suggested with a view to improve resistance of varieties to bolt a possibility based on this behavior. It consists to select bulbs from plants with no floral stalks following an artificial very cold treatment.

Table 4. Main effect of vernalization on the Number of seeds/umbel

\begin{tabular}{ll}
\hline Vernalization treatment & Number of seeds/ umbels \\
\hline $\mathrm{V}_{0}$ & 218.43 \\
$\mathrm{~V}_{1}$ & 412.22 \\
$\mathrm{~V}_{2}$ & 369.67 \\
LSD at $5 \%$ & 3.13 \\
LSD at $1 \%$ & 4.39 \\
Level of significance & $* *$ \\
\hline
\end{tabular}

$\mathrm{V}_{\mathrm{o}}=$ Control, $\mathrm{V}_{1}=$ Vernalization at $5 \pm 1{ }^{\circ} \mathrm{C}, \mathrm{V}_{2}=$ Vernalization at $10 \pm 1^{\circ} \mathrm{C}$, $* *=$ significant at $1 \%$ level of probability

\subsection{Effect of Vernalization on Seed Yield/Plot}

Seed yield per hectare varied significantly increased of cold treatment .The highest seed yield per plot (91.05 g) was found from the cold treatment at $5 \pm 1^{\circ} \mathrm{C}$. The lowest seed yield per hectare was recorded from the plot $(82.07 \mathrm{~g})$ with control. Vernalization significantly influenced seed yield per plot. The highest seed yield (95.89 g) was given by the bulbs those were subjected to vernalization at $5 \pm 1^{0} \mathrm{C}$ and the lowest seed yield $(69.25 \mathrm{~g})$ was given by the bulbs having no vernalization treatment (Fig 6). Increasing seed yield with vernalization treatment was observed by Aguiar et al., (1983) Ershov and Lukonina (1977) also reported that high seed yield was obtained when bulbs were stored at low temperature. Onion, being a biennial crop needs vernalization of bulbs before flowering. The vernalization treatments depend upon the varieties and existing climatic condition.

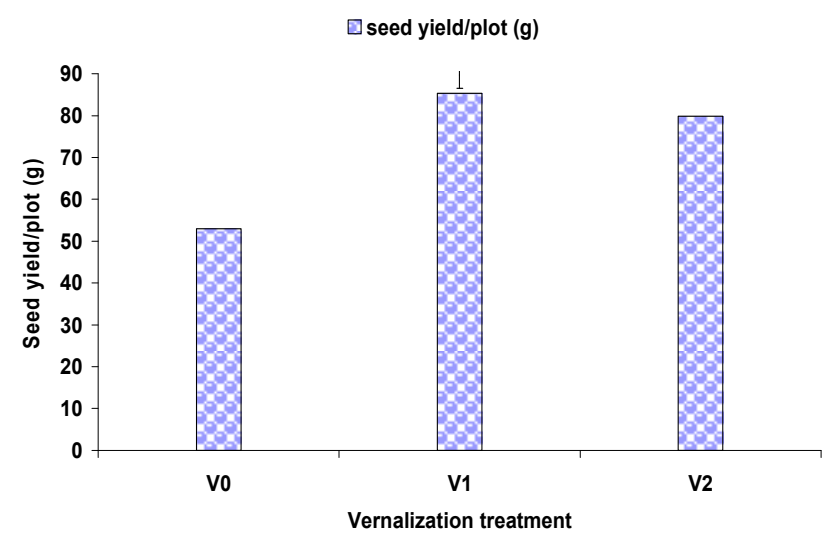

Figure 6. Main effect of vernalization on seed yield/plot. $V_{1}=$ Vernalization at $5 \pm 1^{\circ} \mathrm{C}, V_{2}=$ Vernalization at $10 \pm 1^{\circ} \mathrm{C}, V_{o}=$ Control

\section{Acknowledgement}

All praises are due to the "Omnipotent Allah" Who is the supreme power authority of this universe who enabled us to complete the research work and writing up the thesis for the degree of Master of Science (M.S) in Horticulture. The authors humbly expresses their deepest sense of gratitude, indebtedness and profound appreciation to respectable supervisor Professor Dr. A. M. Farooque, Department of Horticulture, Bangladesh Agricultural University, Mymensingh, for his kind co-operation, valuable guidance, affectionate encouragement, scholastic supervision, constant inspiration, realistic feelings throughout the research period and preparation of this thesis Finally authors like to thanks K.M. Taufiqur Rahman and Md. Fahmid Islam for their endless help during article writing.

\section{References}

[1] Aguiar, P.A., D’oliveira, L.O.B., ASSUNÇÃO, M.V., 1983. Vernalização de bulbos na produção de sementes de cebola nao região do submédio São Francisco. Pesquisa Agropecuária Brasileira, Brasília, 18(7): 741-746.

[2] Aguiar, P.A., 1984. Período de vernalização nos bulbos de cebola para produção de sementes no nordeste do Brasil. Pesquisa Agropecuária Brasileira, Brasília, 19(2): 197-200.

[3] Anonymous.1999.Records of Climatological observations (Daily); May 1998 to April 1999. Weather yard, Department of Irrigation and water Management, Bangladesh Agricultural University, Mymensingh.

[4] BBS., 2001. Monthly Statistical Bulletin, Bangladesh,(September 2001).Bangladesh Bureau of Statistics.Division ,Ministry of planning, Govt. of the peoples Republic

[5] Behairy, A.G., Habbasha, K.M. E., 1979. Onion (Allium cepa L.) seed production as affected by vernalization of bulbs .Zeitschrift fur Acher and Pflanzenbau, 148(2):109-114 [cited from Hort. Abst.,50(1):270,1980'].

[6] Bhardwaj, M.L., ,Rattan R.S., Kohli , U.K., 1991. Effect of Nitrogen,phosphorus and depth of planting on seed production in onion. Indian Journal of Horticulture, 48(3):264-268.

[7] Bokshi, A.I., Mondal, M.F., Pramanik, M.H.R., 1989. Effects of nitrogen and phosphorus fertilizers on the yield and quality of onion seeds. Bangladesh Horticulture, 17(2): 30-35.

[8] Brewster, J.L., 1994. Onions and Other Vegetable Alliums. CAB International, Wallingford, UK, $236 \mathrm{pp}$

[9] Ershov,I.I., Lukonina, E.I., 1977. The effect of the change in temperature during storage of onion mother bulbs on the growth and development of seed plants and on seed yield [Cited from Hort.Abstr.,49(1):369,1969].

[10] Ershov, I. I., Lukonina, E. I., 1977. The effect of the change in temperature during storage of onion mother bulbs on the growth and development of seed plants and on seed yield. Trudy VNII Selektsii i Semenovod Ovoshch Kul' tur, 5: 104111.

[11] FAO.,1999. FAO Yearbook, production 1998. Food and Agriculture Organization of the United Nations, Rome.51:135-136. Bangladesh, Dhaka.54 p.

[12] FAO., 2002. Production Yearbook. Food and Agriculture Organization of the United Nations, Rome, Italy, 58:153. 
[13] Flood, R.G.; HALLORAN, G.M.,1986. Genetics and physiology of vernalization response in wheat. Advances in Agronomy, New York, 39(1): 87-125.

[14] HRDP., 1995. Training Manual; Winter Vegetable and Species Production. Horticulture Research and Development Project (FAO/UNDP/AsDB Project;BGD/87025) and BADC,Dhaka.284p.

[15] Jones, H.A., Mann, L.K., 1963. Onions and their Allies.Leonard Hill, (Books) Ltd., London.pp. 1-169.

[16] Msika, R.L., Jackson, J.E., Currah, L., 1997. Onion seed production trials in the highveld of zimbabwe. Acta Horticulturae. (ISHS) 433:337-346. http://www.actahort.org/books/433/433_36.htm.

[17] Novak, F.J., 1983. Production of garlic tetraploids in shoottip in vitro culture. Z. Planzen. 91:329-333.

[18] Pandey, U.B., eta/. 1992. News/. Assoc. Agric. Develop., 8-12.

[19] Pinthus, M.J., 1985. Triticum. In: HALEY, H.C. CRC Handbook of flowering. Vol. IV. Boca Raton: CRC Press: 418443.
[20] Rabinowitch, H. D., 1990. Physiology of flowering. In: Onion and Allied Crops, ed. H.D. Rabinowitch and J. L. Brewster. Vol. I. CRC Press Inc., Florida:124.

[21] Rahim, M.A., Amin, M.M.U., Haider, M.A., 1993. Onion seed production technologies in Bangladesh. Allium Improvement Newsletter, $3: 33$.

[22] Ramos, D.S.G., Ramos, A.A., 1994. Effect of three length of vernalization on the flowering of onion mother bulbs of three weight classes. Onion Newsletter for the tropics, Venezuela, $6: 48: 51$

[23] Rouamba, A., 1993. Analyse conjointe par les marqueurs agro-morphologiques et les allozymes de la diversité génétique des populations d'oignons (Allium cepa L.) d'Afrique de l'Ouest. Thèse à l'Université Pierre et Marie Curie, Paris, France: 141.

[24] Sanders, D.C and J.D. Cure, 1996Control of bolting in autumn-sown sweet onions through undercutting. J.Amer.soc.Hort.Sci.121:1147-1151. 